\title{
DEVELOPING PSYCHOPEDAGOGICAL AND METHODICAL COMPETENCES IN SPECIAL / INCLUSIVE EDUCATION TEACHERS
}

\author{
Valentin Cosmin Blândul, Adela Bradea \\ University of Oradea, Romania \\ E-mail: bvali73@yahoo.com, adelabradea@yahoo.com
}

\begin{abstract}
In a general sense, competence represents a higher finality which ensures the transfer of acquired theoretical knowledge to effective teaching practices. In the teaching profession, there are three types of competences: professional (they show the teacher's theoretical knowledge), psycho-pedagogical (they concern the teacher's ability to know their students and to establish interhuman relationships with them) and methodical (concerns the teacher's ability to teach effectively the elements of the didactic content). Due to the particularities of special / inclusive education, teachers involved in this form of education should possess mainly psycho-pedagogical and methodical competences so that they can meet successfully the educational needs of students with disabilities. The aim of the research was to identify the psycho-pedagogical and methodical competences of special / inclusive education teachers, as well as ways to improve them using continued professional training activities. The sample consisted of 225 teachers, who work in various forms of special education in Bihor County, Romania. The instrument consisted of a questionnaire with 21 items. The research was conducted in April 2017. The results of the research showed that special education teachers are more empathetic and use a more diversified range of didactic strategies, while inclusive education teachers are concerned with continued professional training in the field of special education.
\end{abstract}

Keywords: didactic competences, people with disabilities, special / inclusive education.

\section{Introduction}

The term competence has a polysemantic nature. Out of the great number of definitions (Boutin, 2004, Tardif, 2003, Aubret \& Gilbert, 2003, Chiş, 2006, Potolea \& Toma, 2010, Wahlgren, 2016 and others), the one which is complete and functional in connection with the training for the teaching career could be chosen: competence is the proven capacity to adequately choose, combine and use knowledge, abilities and other acquisitions consisting of values and attitudes to successfully solve a certain category of work or learning situation, as well as to achieve professional or personal development effectively and efficiently. In this sense, the structural elements of a competence are: the professional roles or the work / learning tasks which should be carried out, performance standards, the context, the knowledge, the abilities and personality / attitude characteristics. These structural elements concern not only the development of professional training programmes, but also their implementation and evaluation (Potolea \&Toma, 2010, 2013).

Teachers' competences are structured in three types: (1) scientific / professional competence, which means thorough knowledge of the subject taught and, at the same, an excellent cooperation capacity with other experts; the capacity to engage the affective and ethic components of the didactic process along with that of detailing, sustaining and arguing for topics related to the field of knowledge; (2) methodical competences - the capacity to know the students and to take into consideration age specific requirements, as well as individual characteristics, in the process of planning and implementing instructive-educational activities; the capacity to shape, to develop the main personality components of each student; the capacity to communicate with the students, to influence and motivate them to learn; the capacity to make accessible the 
Valentin Cosmin BLÂNDUL, Adela BRADEA. Developing psychopedagogical and methodical competences in special / inclusive education teachers

PROBLEMS

OF EDUCATION

IN THE $21^{\text {st }}$ CENTURY Vol. 75, No. 4, 2017

336

content of the subject taught, to understand the subjects of the didactic relationship; the capacity to train the students for self-training and self-education. (3) psycho-pedagogical / psychosocial competences - the capacity to optimise the interhuman and interpersonal relationships required in the didactic process: assuming the set of roles needed for this process; establishing easily relationships with the partners of the process; the capacity to organise the students with regard to the tasks of training and to establish cooperative relationships, an adequate climate within the group of students and to resolve conflicts; the capacity to assume responsibilities; the capacity to guide, organise and coordinate, advise and motivate, to take decisions depending on the situation; the capacity to communicate easily, effectively, to use in a proper way power and authority along with understanding; the diversity of styles used to make the students aware of the necessity of learning, as well as to establish effective relationships with beneficiaries, parents, communities and other institutions.

The system of standards developed observes the provisions of the Romania law, which states that "the continued training of teachers is based on the model of competence approach and on the concept of cumulative development of the teaching staff's level of competence" (art.6.) and concerns: "professionalization of the teaching career; placing of the training system in the European context of continued professional development / lifelong learning and training, and orientation of the training system towards mobility and evolution in career and professional development" (art. 90, Methodology of continued training).

\section{Problem of Research}

Teachers' competences should be a means to serve the development of children, students and other beneficiaries of the teaching process. Developing, and from time to time updating, professional standards concerning evolution in the teaching career has been and should be determined by the idea that professional standards do not represent just a technical problem, but they should also be associated with the values of education (Potolea \& Toma, 2013).

The very system of values is what guides teachers' professional competences towards a direction or another (Pânișoară, 2009). In the teaching, learning and evaluation processes, teachers, regardless the educational stage they are active in, should respect the principles and rules of professional ethics, promote a responsible attitude towards the teaching activity, respect the students' rights, their personality and uniqueness, as well as the parents' rights in their relationship with their children, supporting and encouraging them. The acknowledgement and respect of diversity and multiculturalism are correlated with the acknowledgement and respect of individual differences and the rejection of any form of discrimination, and it is proved by prosocial behaviour and civic participation.

The training of teachers is a continued process which includes two compulsory stages: the initial training, which enables those graduating from various forms of institutions which provide qualifications (pedagogical high schools, universities) to join the education system, and continued training, which is performed through courses addressed to teachers after they have joined the education system. In Romania, the initial training focuses mainly on specialisation in a certain field and less on the methodical aspect. The importance of the latter one for the teaching career is apparent and it entails acquiring knowledge about modern teaching methods, cooperative learning, class management and conflict resolution. Thus, university graduates in Romania are very good experts in the subjects they have studied, buy they are not equally good as teachers. They need a long period of practical training before they can join the teaching profession. Continued training was initially provided primarily by universities and, therefore, it was mainly theoretical and did not take into account the changes brought by the reform of the pre-university education. For that reason, after some public debates concerning the reform of the training of teachers, the Ministry of National Education set forth the objectives of pre-university teachers' initial and continued training: professionalization of the teaching career in Romania, changing the ratio between the theoretical and practical components in the training curriculum 
of teachers by extending the route of initial training to the moment of obtaining a teacher /

PROBLEMS

OF EDUCATION

IN THE $21^{\text {st }}$ CENTURY

Vol. 75, No. 4, 2017

primary school teacher diploma by passing a ,professional certification” exam, developing a „market of the continued training programmes” based on fair competition, correlating structures and moments of the teaching career with educational standards and ensuring the dynamics of the profession by using the system of professional credit transfer, as well as the development of modern institutional structures in order to optimize teachers' continued training activities.

\section{Research Focus}

There are many teachers who consider that a child's failure is entirely their fault because they have not been able to meet the requirements of the system: they believe that it is a child's duty to reach the standards imposed by the system. Few teachers understand and accept the fact that a child's failure is also the teacher's failure and that school should adjust itself to the child's needs and not the other way around. Some teachers are capable of changing and are open to change, which means they are willing to adopt an individualized working style, focused on the child's needs. All Romanian citizens have the same right to education, at all stages and in all forms, regardless their gender, race, nationality, religion or political affiliation and regardless their social or economic status. Education is free in the public educational institutions and the state guarantees the right to education on behalf of the individual and on that of society. In Romania, children with disabilities have access to different forms of education and can be enrolled, depending on the degree of the disability, in the special education system or in the mainstream education. Children with moderate deficiencies, with learning difficulties and speech disorders, socio-emotional disorders or behaviour problems are integrated into mainstream school, where they can benefit from educational support services.

A limited number of mainstream schools have integrated so far children with special educational needs (SEN). In Romania, inclusive schools do not yet exist in the true meaning of the word, the educational support services are barely developed and ineffective, and the community's mentality has not really improved regarding the inclusion of all children in any school. For all that, in recent years, some NGOs have implemented several projects to establish inclusive schools in Romania. Despite these efforts, the Romanian society still has a segregationist approach to people with disabilities and the above mentioned examples could not be extended at national level. However, the Ministry of Education has promoted some projects at country level with the aim of creating the starting points of a coherent and effective reform. Unfortunately, mainstream education teachers are not yet prepared to work with children whose performances are different. They have not been trained to adjust their teaching to children with different levels of intellectual development or to help children with poor performances to improve their results. The Ministry of Education has made significant efforts, with the support of NGOs, to ensure the continued training of mainstream education teachers in order to help them understand and accept the differences between children, to adjust the curriculum and working methods to the needs of children and to adopt an inclusive approach in the class.

Taking into account the things mentioned above, the current research focused on the training level of special education / inclusive education teachers, that is, on their professional, psycho-pedagogical and methodical competences which enable an effective personalized approach to the students with SEN.

\section{Methodology of Research}

\section{General Background}

Summarizing the things presented above, it can be said that a successful teacher is a person with an excellent professional knowledge, capable of teaching the theoretical knowledge they have acquired, as well as of establishing constructive interhuman relations with their 
Valentin Cosmin BLÂNDUL, Adela BRADEA. Developing psychopedagogical and methodical competences in special / inclusive education teachers

PROBLEMS
OF EDUCATION

IN THE $21^{\text {st }}$ CENTURY Vol. 75 , No. 4,2017

338

students. Due to the psycho-individual particularities of students with SEN - which quite often limit their cognitive possibilities to acquire higher level didactic contents - Ghergut, Frumos and Raus (2016) recommend that special / inclusive education teachers develop first of all their psycho-pedagogical and methodical competences, insisting on the emotional aspect of the teaching process. In light of these considerations, the aim of this research was to identify special / inclusive education teachers' development level of didactic competences, as well as those ways by which they can be optimized. The objectives of the research were the following: (1) analysis of teachers' perception of the development level of their own general competences to teach children with SEN; (2) self-assessment of the development level of specific competences (psycho-pedagogical and methodical) needed by teachers working in the field of special education, as well as (3) identifying the need for continued professional training in the case of this category of teachers. The specific hypothesis of this research was: there are no statistically significant differences between the development level of competences needed to teach children with SEN in the case of special education teachers and in that of special inclusive education ones.

\section{Sample}

The sample of research consisted of 225 special / inclusive education teachers from Bihor county, Romania $(\mathrm{N}=225)$, of whom $113(50.22 \%)$ are special education teachers, and $112(49.88 \%)$ special inclusive ones. The narrative presentation which follows is based on the need of giving an overall picture of the entire sample. $69.9 \%$ of the total number of respondents were females, and $30.1 \%$ males. $55.3 \%$ of them had bachelor's degrees, and $44.7 \%$ master's degrees. Regarding their years of teaching, they belonged to the following categories: less than 5 years $-23.8 \%$, between 6 and 10 years $-9.2 \%$, between 11 and 15 years $-18.7 \%$, above 16 years $-48.3 \%$. $48.6 \%$ of them teach in rural areas, and $51.4 \%$ in urban ones. Regarding the school stage, $8.7 \%$ teach in preschools, $30.4 \%$ in primary schools and $60.9 \%$ in secondary and upper-secondary schools. The simple random sampling procedure was used for choosing the respondents, which represents approximately $22 \%$ of the active teaching staff of Bihor County, Romania.

\section{Instrument and Procedure}

The instrument used in this research consisted of a scale-based questionnaire which was devised to enable the self-assessment of the professional knowledge, psycho-pedagogical and methodical training levels of special education teachers. The instrument included 21 multiplechoice items grouped in several categories, of which, for this research, only those were used that referred to the self-assessment of the development level of the general didactic competences needed in special education, of the psycho-pedagogical and methodical competences, as well as of those about the interest in their continued professional training. The self-assessment scale had 6 levels, with „1" meaning „Strongly disagree”, and „6" - „Strongly agree”. The instrument was prepared by the educationalists who participated in an Intensive Programme on Special Education held in the first half of 2017 at the Polytechnic Institute of Guarda, Portugal within the project ,, Teaching and Learning in Special Education with ICT” - www.teleseict.org (Erasmus+ KA2). It was printed and each respondent filled in their copy individually in MarchApril 2017.

\section{Data Analysis}

The quantitative interpretation of the results was performed by calculating the statistical frequency of the answers given by the respondents. In addition, the answers given by the special education teachers and those of the inclusive education ones were comparatively analysed. 
Valentin Cosmin BLÂNDUL, Adela BRADEA. Developing psychopedagogical and methodical competences in special / inclusive education teachers

The statistical processing of the values obtained was performed by calculating the $\chi^{2}$ (chi square) criterion for the relations between the form of education - special or inclusive - and the development level of the psycho-pedagogical and methodical competences in the area of special education.

\section{Results of Research}

The results of the research are presented in the following tables, where the rows show the answers from the entire sample, as well as from the two sub-categories (special education teachers and inclusive education ones), and the columns include the 6 levels of the scale.

Table 1. Self-assessment of the development level of the general didactic competences needed by teachers to teach students with SEN (\%).

\begin{tabular}{lllllll}
\hline Score & 1 & 2 & 3 & 4 & 5 & 6 \\
\hline I possess general competences to teach students with SEN & & & & & \\
\hline General answers $(\mathrm{N}=225)$ & 8 & 32 & 16 & 24 & 20 & 0 \\
\hline Special education teachers $(\mathrm{N}=113)$ & 0 & 7.7 & 23.1 & 38.62 & 30.58 & 0 \\
\hline Inclusive education teachers $(\mathrm{N}=112)$ & 17.09 & 57.92 & 8.33 & 8.33 & 8.33 & 0 \\
\hline
\end{tabular}

The results in Table 1 show that the teachers have a rather low perception concerning their own general level of training in the area of special education. The results for the entire sample show that there is no polarization of answers around a certain value, but, on the contrary, a distribution along the entire scale. Looking at the two sub-categories of the sample, it can be seen that the special education teachers consider themselves somewhat better prepared than their colleagues who teach students with SEN integrated in mainstream education. This situation can be explained by the training provided to teachers who decide to choose a career in special education. In order to be allowed to work as staff teachers in the special education system, teachers need a qualification in the area of special psychopedagogy, which means a bachelor's degree with a total of 180 ECTS (in 3 years of study) and, possibly, a master's degree with 120 ECTS (2 years of study). On the contrary, teachers who want to teach in the special inclusive education need a bachelor's / master's degree, regardless the field of studies, but they should also attend a postgraduate continued professional training course in the field of special school psychopedagogy, with a total of 60 credits. The differences between the professional training levels of the two categories of teachers are obvious, although the job requirements seem to be rather similar, a fact that can explain the uncertainty of inclusive education teachers regarding the self-assessment of their own special education didactic competences. 
Valentin Cosmin BLÂNDUL, Adela BRADEA. Developing psychopedagogical and methodical competences in special / inclusive education teachers

PROBLEMS

OF EDUCATION

IN THE $21^{\text {st }}$ CENTURY Vol. 75 , No. 4, 2017

Table 2. Self-assessment of the development level of the psycho-pedagogical competences of teachers who teach students with SEN (\%).

\begin{tabular}{|c|c|c|c|c|c|c|}
\hline Score & 1 & 2 & 3 & 4 & 5 & 6 \\
\hline \multicolumn{7}{|c|}{$\begin{array}{l}\text { I possess psycho-pedagogical competences needed to establish an empathetic relationship in the educational envi } \\
\text { ronment }\end{array}$} \\
\hline General answers $(\mathrm{N}=225)$ & 0 & 4 & 12 & 28 & 40 & 16 \\
\hline Special education teachers $(N=113)$ & 0 & 0 & 7.7 & 15.4 & 53.8 & 23.1 \\
\hline Inclusive education teachers ( $N=112$ ) & 0 & 8.33 & 16.68 & 41.66 & 25 & 8.33 \\
\hline \multicolumn{7}{|c|}{ I possess psycho-pedagogical competences needed for effective communication } \\
\hline General answers $(\mathrm{N}=225)$ & 0 & 4 & 0 & 20 & 44 & 32 \\
\hline Special education teachers $(N=113)$ & 0 & 7.7 & 0 & 23.1 & 38.44 & 30.76 \\
\hline Inclusive education teachers ( $N=112$ ) & 0 & 0 & 0 & 16.66 & 50 & 33.34 \\
\hline \multicolumn{7}{|c|}{ I possess psycho-pedagogical competences needed to motivate students } \\
\hline General answers $(\mathrm{N}=225)$ & 0 & 4 & 0 & 12 & 40 & 44 \\
\hline Special education teachers $(N=113)$ & 0 & 7.7 & 0 & 15.4 & 53.8 & 23.1 \\
\hline Inclusive education teachers ( $N=112$ ) & 0 & 0 & 0 & 8.34 & 25 & 66.66 \\
\hline
\end{tabular}

Table 3. Self-assessment of the development level of the methodical competences of teachers who teach students with SEN (\%).

\begin{tabular}{lllllll}
\hline Score & $\mathbf{1}$ & $\mathbf{2}$ & 3 & $\mathbf{4}$ & $\mathbf{5}$ & $\mathbf{6}$ \\
\hline I possess methodical competences needed for the effective use of didactic resources & & & \\
\hline General answers $(\mathrm{N}=225)$ & 4 & 0 & 0 & 20 & 40 & 36 \\
\hline Special education teachers $(\mathrm{N}=113)$ & 7.7 & 0 & 0 & 30.74 & 38.46 & 23.1 \\
\hline Inclusive education teachers $(\mathrm{N}=112)$ & 0 & 0 & 0 & 8.34 & 41.66 & 50 \\
\hline I possess methodical competences needed for the personalization of the instructive-educational process & \\
\hline General answers $(\mathrm{N}=225)$ & 4 & 4 & 8 & 20 & 20 & 44 \\
\hline Special education teachers $(\mathrm{N}=113)$ & 0 & 0 & 7.7 & 15.9 & 15.4 & 61 \\
\hline Inclusive education teachers $(\mathrm{N}=112)$ & 8.33 & 8.33 & 8.33 & 25 & 25 & 25 \\
\hline
\end{tabular}

The detailed analysis of the sub-categories of psycho-pedagogical and methodical competences needed in special education shows that most of the respondents self-assess themselves with , 5 " on a scale from „1" to „6". Thus, regarding the psycho-pedagogical competences, the results show that special education teachers have higher empathetic competences, while their inclusive education colleagues have high levels of communication and motivational competences (Table 2). On the other hand, as far as the methodical competences are concerned, those who teach in the special inclusive schools have better developed abilities in the management of available educational resources, while the special education teachers 
Valentin Cosmin BLÂNDUL, Adela BRADEA. Developing psychopedagogical and methodical competences in special / inclusive education teachers

are successful in personalizing the instructive-educational process addressed to students with various disabilities (Table 3). The explanation of this aspect may lie in the curriculum of bachelor's / master's or postgraduate training programmes in special psychopedagogy. Thus, the focus in the case of students who opt for the aforementioned major for their studies is on knowing the psycho-individual characteristics of students with different types of disabilities, as well as on the methodology of teaching in the case of these students, centred, mainly, on developing personalized intervention plans. Such elements are less frequent in the curriculum of other faculties which train future teachers and which insist on psychosocial contents (understanding the student's personality, communication, motivation, relating to others within the school community and so on), or on the teaching methodology for students without special educational needs. That can explain why special education teachers are better prepared in aspects related to methodology, while those involved in the inclusive education in psychopedagogical and psychosocial issues.

Table 4. Self-assessment of teachers' motivation to participate in continued professional training in the field of special education (\%).

\begin{tabular}{lllllll}
\hline Score & 1 & 2 & 3 & 4 & $\mathbf{5}$ & $\mathbf{6}$ \\
\hline I am motivated to take part in professional training programmes in special psychopedagogy & & \\
\hline General answers $(\mathrm{N}=225)$ & 0 & 0 & 0 & 4 & 32 & 64 \\
\hline Special education teachers (N = 113) & 0 & 0 & 0 & 0 & 38.46 & 61.54 \\
\hline Inclusive education teachers $(\mathrm{N}=112)$ & 0 & 0 & 0 & 8.34 & 25 & 66.66 \\
\hline
\end{tabular}

According to the results in Table 4, more than $60 \%$ of the respondents feel the need for training in the field of special psychopedagogy. The polarization of answers around the highest level of the scale can be noticed in the case of both categories of the sample, which is due to the complexity of working with students with SEN. Thus, regardless of learning in a special school or being integrated into a class / school along with other students with no disabilities, students with SEN have a number of physical, psycho-intellectual and psycho-emotional particularities which require increased attention and support from their teachers. The most severe cases can be found in the special education schools, while the students who can cope with the requirements of mainstream schools have the possibility to study in special classes of public schools, or, in well-justified situations, in regular classes, along with the other classmates. Nevertheless, the work of teachers who teach such students with SEN will still be a very complex one, which requires a thorough professional, psycho-pedagogical and methodical training.

Table 5. Statistical differences between the development level of competences of special education teachers and the form of education they teach in.

\begin{tabular}{lll}
\hline \multirow{2}{*}{ Indicators: } & \multicolumn{2}{c}{ Teachers } \\
\cline { 2 - 3 } & Special education & Special inclusive education \\
\hline $\begin{array}{l}\text { Differences between the development level of com- } \\
\text { petences of special and special inclusive education } \\
\text { teachers }\end{array}$ & $\chi^{2}=10.53$ & $\chi^{2}=13.28$ \\
\cline { 2 - 3 } & $p<.01$ & $p<.05$ \\
\hline
\end{tabular}



education teachers

OF EDU

PROBLEMS

IN THE $21^{\text {st }}$ CENTURY Vol. 75 , No. 4, 2017

342

The specific hypothesis of this research was that there are no statistically significant differences between the development level of competences needed to teach students with SEN in the case of special education teachers and in that of the special inclusive ones. The results presented in Table 5 show that the specific hypothesis was validated, as the statistical differences are significant at $\mathrm{p}<.01$ in the case of special education teachers and at $\mathrm{p}<.05$ for the special inclusive ones. These results demonstrate a higher development level of competences in the case of teachers belonging to the first category, which can be explained by a more thorough and longer time in professional training. The need for a comprehensive professional training in the case of teachers who teach students integrated into mainstream education is apparent again, as in this way they will be able to successfully cope with the challenges of an educational activity of this type.

\section{Discussion}

The interpretation of the quantitative and qualitative results of the research makes it possible to build the socio-professional profile of the special and special inclusive education teachers. Thus, the former ones are people with bachelor's or master's degrees in the area of special psychopedagogy, have competences in the evaluation, diagnosis, therapy, rehabilitation, education, professionalization and monitoring the evolution of students with various disabilities. Therefore, the socio-professional profile of these teachers includes elements such as: the capacity to teach students with SEN in a personalized pace, adjusted to their needs, a good capacity for empathy, knowledge and attention given to age specific requirements, support given to students so that they can cope with school tasks and so on. On the other hand, the special inclusive education teachers can have bachelor's or master's degrees in specializations connected to special education or in any other field of study, provided that they have completed a postgraduate course in the field of special school psychopedagogy. As a result, their training in the area of special education might be without depth, their area of competences being limited to recognizing the problems faced by students with SEN, to using didactic strategies which can be applied to this category of students too, and to empathic communication within the school community. It is necessary, therefore, to develop these psycho-pedagogical and methodical competences of special education teachers, which can be achieved by involving them in projects developed in this field of specialization, or by completing continued professional training courses (Fernández, 2013, Wahlgren, 2016, Mrnjaus, 2012).

The second important aspect worth discussing is the need for continued professional training of teachers who work in the field of special education. Romanian researchers (Ghergut, Frumos, Raus, 2016), argue that in order to successfully integrate students with SEN, teachers should form and develop professional, psycho-pedagogical and methodical competences by covering several distinct stages in time: (1) Raising awareness: in the first stage the school environment should be prepared, starting from the school leadership, and the teachers in particular, by information actions. (2) Training: teachers should be included in a training program so that they can learn about the students' specific problems and understand their behaviour and learn principles, methods and techniques which are appropriate for the instructive-educational activities carried out for children with deficiencies. (3) Decision making: involves reorganising the functional structures of the school and reviewing the attitude of all staff members towards the new form of school organisation. (4) Transition: it is the most difficult stage, as it assumes the implementation of the new working methods. Teachers should take into account that any learning process (especially in the case of students with SEN) is more effective and easier to understand if the information presented is demonstrated and applied in real life situations, with a continuous feedback being provided. It is recommended that those who work in the field of special education should apply learning strategies which focus on cooperation, collaboration and communication between students during didactic activities, as well as on interaction between teachers and students. Therefore, many authors (Avramidis \& Norwich, 2002, Newton 
et al., 2014) recommend that special education teachers attend a number of professional training programmes in order to develop these very types of competences. Unfortunately, there are
many schools where the teachers have not attended any training courses in this field. As a result, they are not prepared to face the problems which arise in their work with special education students, they feel uncertain, ill-prepared, which leads to an ineffective didactic activity with these children.

\section{Conclusions}

Integration of students with SEN into mainstream schools is a challenge for any country of the world, regardless how much is invested in this process. This fact gives the school institution the role of fundamental component of the social system, capable to give concrete answers to the current imperatives set by the evolution of the contemporary society and to resolve a series of problems related to the need for social acceptance / valorisation of each individual and to their capacity to integrate into a continuously changing society. In order to fulfil these expectations, the effective teacher should also be concerned with the progress of their students, maximising the time when students are engaged in their tasks and the school learning time. Several of the teacher's personality traits leave their marks on the school achievement, therefore they should be constantly concerned with their own professional training. A constant development of the professional, psycho-pedagogical and methodical competences, coupled with a continuous reflection process, will improve the quality of their own didactic performance, as well as the quality of training the young generation.

\section{References}

Aubret, J., \& Gilbert, P. (2003). L'évaluation des competences [Assessment of Competences]. Sprimont: Pierre Mardaga.

Avramidis, E., \& Norwich, B. (2002), Teachers' attitudes towards integration / inclusion: A review of the literature. European Journal of Special Needs Education, 17 (2), 129-147.

Boutin, G. (2004). L'approche par compétences en éducation: un amalgame paradigmatique [Competencebased approach in education: A paradigmatic amalgam]. Connexions, 81 (1), 25-41.

Chiş, V. (2006). The new curriculum - the curriculum for competences. Didactica universitară. Discipline socio-umane [Academic didactics. Socio-human disciplines]. Cluj-Napoca: Argonaut, 17-41.

Fernández, J. T. (2013). Professionalisation of teaching in universities: Implications from a training perspective. International Journal of Educational Technology in Higher Education, 10 (1), $345-$ 358. DOI: 10.7238/rusc.v10i1.1471.

Gherguţ, A., Frumos, L., Raus, G. (2016). Special education. Methodical guide. Iaşi: Polirom Press.

Mrnjaus, K. (2012). Teacher competences for education for democratic citizenship. Training and classification challenges. Schools. Curriculum and Civic Education for Buildings Democratic Citizen, 2, 81-97. DOI: 10.1007/978-94-6209-167-2_7.

Newton, N., Hunter-Johnson, Y., Gardiner-Farquharson, B. L., Cambridge, J. (2014). Bahamian teachers perceptions of inclusion as a foundational platform for adult education programs. International Journal of Special Education, 29 (3), 26-37.

Pânișoară, I. O. (2009). The successful teacher. 59 principles of practical pedagogy. Iași: Polirom Press.

Potolea, D., \& Toma, S. (2010). Competence: The concept and implications for the training programmes of adults. The Third National Conference on Adult Education, 19-21 March 2010, Timişoara. Retrieved 2/05/2017, from https://pt.scribd.com/document/336545347/volum-3-Educatiaadultilor-Sava-pdf.

Potolea, D., \& Toma, S. (2013). Standards for the teaching profession. Education Congress, 14-15 June 2013, Bucureşti. Retrieved 2/05/2017, from http://www.congresuleducatiei.ro/ckfinder/userfiles/ files/SToma_\%20DPotolea.pdf.

Tardif, J. (2003). Développer un programme par compétences: de l'intention a la mise en æeuvre [Developing a competence-based programme: From intention to implementation]. Pédagogie Collégiale, 16 (3), 36-44. 
Valentin Cosmin BLÂNDUL, Adela BRADEA. Developing psychopedagogical and methodical competences in special / inclusive education teachers

PROBLEMS

OF EDUCATION

IN THE $21^{\text {st }}$ CENTURY Vol. 75 , No. 4, 2017

344

Wahlgren, B. (2016). Adult educators' core competences. International Review of Education, 62 (3), 343-353.

Ministry of Education (2011, October, 7). The methodology on the continued training of the teaching staff. Retrieved 2/05/2017, from https:/www.edu.ro/formare-continua.

Received: June 15, 2017

Accepted: August 22, 2017

\begin{tabular}{ll} 
Valentin Cosmin Blândul & PhD, Professor, University of Oradea, 1 University Street, Oradea, 410087, \\
& Bihor, Romania. \\
& E-mail: bvali73@yahoo.com \\
& Website: www.uoradea.ro \\
\hline Adela Bradea & PhD, Associate Professor, University of Oradea, 1 University Street, Oradea, \\
& 410087, Bihor, Romania. \\
& E-mail: adelabradea@yahoo.com \\
& Website: www.uoradea.ro
\end{tabular}

